\title{
Hematinic effects of Spondias mombin and its protective role against the spleenotoxic effect of phenylhydrazine
}

\author{
Silvanus Olu Innih', Sylvia Oghogho Omage ${ }^{2}$ and Kingsley Omage ${ }^{3^{*}}$ (D)
}

\begin{abstract}
Background: This study was aimed at evaluating the hematinic effect of Spondias mombin and its protective role against the spleenotoxic effect of Phenylhydrazine (PHZ).

Methods: Thirty Wistar rats were randomized into 6 groups. Group A (Control) animals were neither given the extract nor PHZ. Rats in groups B and C were administered $150 \mathrm{mg} / \mathrm{kg}$ body weight and $300 \mathrm{mg} / \mathrm{kg}$ body weight doses of the extract respectively. Anemia was induced in rats in groups $D$ and $E$ by oral administration of $40 \mathrm{mg} / \mathrm{kg}$ body weight of $\mathrm{PHZ}$ and concomitantly administered $150 \mathrm{mg} / \mathrm{kg}$ body weight and $300 \mathrm{mg} / \mathrm{kg}$ body weight doses of the extract respectively. Anemia was also induced in rats in group F by administration of $40 \mathrm{mg} / \mathrm{kg}$ body weight of PHZ but without administration of the extract.

Results: Histology of the spleen show moderate expansion of the red pulp and contraction of lymphoid follicles in group $\mathrm{F}$ and mild follicular activation and sinus histiocytosis in group D. There were significant $(p<0.05)$ increase in the weight of the spleen in group $F$ and decrease in group $C$. Results also show significant $(p<0.05)$ decreases in the RBC count in group $F$ and increases in the Mean Corpuscular Volume and Mean Corpuscular Haemoglobin in groups $D$ and E. There was also a significant $(P<0.05)$ decrease in the Mean Corpuscular Haemoglobin Count in group D.
\end{abstract}

Conclusion: This study shows the hematinic effect of Spondias mombin and its possible use in ethno-medicine in managing anemic conditions, as well as its potential in protecting against the spleenotoxic effect of $\mathrm{PHZ}$.

Keywords: Spondias mombin, Phenylhydrazine, Hematinic, Spleenotoxic, Histiocytosis

\section{Introduction}

The spleen plays important roles in the mobilization or recycling of red blood cells and immune function [1]. It is the largest single aggregate of lymphoid tissue in the body [2] and a center of activity of the mononuclear phagocyte system [3]. It can be considered analogous to a large lymph node, as its absence causes a predisposition to certain infections [3]. A non-functional spleen may cause a modest increase in circulating white blood cells and platelets, a diminished response to some vaccines, and an increased susceptibility to infection [4].

\footnotetext{
* Correspondence: omagekingsley@yahoo.com

${ }^{3}$ Department of Biochemistry, College of Basic Medical Sciences, Igbinedion University, Okada, Benin City, Edo State, Nigeria

Full list of author information is available at the end of the article
}

Some drugs like phenylhydrazine (PHZ) have been shown to affect the spleen thereby reducing its functions. Phenylhydrazine (PHZ), an antipyretic drug that is normally taken to treat fever [5], has been known to induce anemia for over decades, with subsequent increase in the numbers of erythrocyte-committed-progenitorcolony-forming units [6]. PHZ-induced anemia had been used as a model for the evaluation of its influence on some therapeutic effectiveness [7], as a model of reticulocyte researches or erythrocyte senescence [8], and as a model for the study of hematinic effects [9]. In ethno medicinal practices, these hematinic effects have been managed with the use of medicinal plants.

Plants are essential in human health care and the use of herbs to treat disease is almost universal among non- 
industrialized societies [10]. A number of modern drugs have been derived from plants $[11,12]$ through observations of traditional cure methods of indigenous peoples [13]. At present, researches into medicinal plant uses in African show that traditional medicine is commonly used to treat or manage various disorders in the West African region [12, 14]. These medicinal plants are considered as rich resources of phytochemicals and nutraceuticals which can be used in drug development and synthesis $[15,16]$. These phytochemicals and nutraceuticals also play important roles in reducing the occurrence of many diseases by improving various organ functions of the human body $[15,17]$. Spondias mombin L. (species S. mombin) also known as yellow mombin or hog plum belongs in the family Anacardiaceae and is native to the tropical Americas and the West Indies. It is a small deciduous tree, with thick bark, which grows up to about $20 \mathrm{~m}$ of height. Spondias mombin is a flowering plant whose leave extracts has been known to possess pharmacological activities. The plant extract has been shown to possess phytochemicals like sterols, triterpenes, saponins, as well as phenolic derivatives with antiherpes and antioxidant properties [18]. Reports have shown the anxiolytic effect [19], sedative, antiepileptic and antipsychotic effects of the leaves extract in mice and rats [20]. It has been suggested that the presence of whole constituents of the leaf may be a requirement for uterotonic activity [21]. Spondias mombin extract possess some insulin-like properties [22]. The juice of the crushed and the powdered dried leaves is used as poultices on wounds and various inflammatory conditions [23]. The decoction of the astringent bark serves as emetic a remedy for hemorrhoids [24]. It has been stated that essential oil derived from the leaves of Spondias mombin could hold promise for future application in the treatment of cancer-related diseases [25]. In ethno-medicinal practice, Spondias mombin is often used in the management of anemic conditions, although this has not been scientifically rationalized. Other researchers have shown that some medicinal plants possess hematinic properties and are therefore useful in the management of anemia [26-28]. Thus in this study, our aim was to evaluate the hematinic effect of Spondias mombin and its protective role against the spleenotoxic effect of PHZ.

\section{Methods}

\section{Collection of Spondias mombin leaves}

Mature Spondias mombin leaves were harvested from local farms within Ugbowo town in Benin City. The leaves were identified and authenticated at the Herbarium in the Department of Pharmacognosy, Faculty of Pharmacy, University of Benin.

\section{Preparation of aqueous leaf extract of Spondias mombin} The leaves were washed under running tap water followed by rinsing with distilled water. They were shade-dried in the laboratory at room temperature and ground into fine powder using an electric blender (pyeUnicam, Cambridge, England). About $100 \mathrm{~g}$ of the powdered leaves was soaked in $400 \mathrm{ml}$ distilled water for $48 \mathrm{~h}$ at room temperature, with occasional stirring using the magnetic stirrer, after which the mixture was filtered using Watman filter paper number 1. The filtrate was concentrated using a rotary evaporator to produce a gel-like aqueous leaf extract. The respective doses administered were subsequently prepared by appropriate dilution of the concentrated aqueous leaf extract.

\section{Experimental animals}

Thirty Wistar rats of both sexes weighing between 180 and $260 \mathrm{~g}$ were used as experimental animals in this study. The rats were purchased and maintained at the animal house of the Department of Anatomy, University of Benin. They were kept in cleaned disinfected cages made of wood and wire gauze at the top to allow proper ventilation. The experimental rats were allowed to acclimatise for a period of 1 week in these cages. They were allowed free access to feed (livestock grower's marsh manufactured by Bendel Feeds and Flour Mills limited, Ewu, Edo States, Nigeria) and water all through the duration (4 weeks) of the experiment.

\section{Experimental design and procedure}

The experimental rats were randomly assigned into six groups $(\mathrm{A}-\mathrm{F})$ of five animals each. Group A animals which served as the control were neither given the aqueous extract nor phenylhydrazine (PHZ). Animals in groups $\mathrm{B}$ and $\mathrm{C}$ were administered $150 \mathrm{mg} / \mathrm{kg}$ body weight (low) and $300 \mathrm{mg} / \mathrm{kg}$ body weight (high) doses of the aqueous leaf extract respectively. Anemia was induced in animals in groups D and E by oral administration of $40 \mathrm{mg} / \mathrm{kg}$ body weight of PHZ and concomitantly administered $150 \mathrm{mg} / \mathrm{kg}$ body weight (low) and $300 \mathrm{mg} / \mathrm{kg}$ body weight (high) doses of the extract respectively. Anemia was also induced in animals in group $\mathrm{F}$ by oral administration of $40 \mathrm{mg} / \mathrm{kg}$ body weight of $\mathrm{PHZ}$ but without administration of the aqueous leaf extract. The period of administration and induction lasted for 21 days. Spondias mombin aqueous leaf extract was administered orally using an orogastric tube [29]. The experimental procedures and care of the animals were in accordance with institution's (School of Basic Medical Sciences, University of Benin, Nigeria) animal and ethics guidelines.

The design is as illustrated below; 


\begin{tabular}{lll}
\hline Groups & Designation & Administration Regimen \\
\hline A & Control & Normal feed and water \\
B & $\begin{array}{l}\text { Low Dose } \\
\text { Extract }\end{array}$ & $\begin{array}{l}150 \mathrm{mg} / \mathrm{kg} \text { body weight of Spondias } \\
\text { mombin aqueous leaf extract only }\end{array}$ \\
C & $\begin{array}{l}\text { High Dose } \\
\text { Extract }\end{array}$ & $\begin{array}{l}300 \mathrm{mg} / \mathrm{kg} \text { body weight of Spondias } \\
\text { mombin aqueous leaf extract only }\end{array}$ \\
D & $\begin{array}{l}\text { High Dose } \\
\text { Extract and PHZ }\end{array}$ & $\begin{array}{l}300 \mathrm{mg} / \mathrm{kg} \text { body weight of Spondias } \\
\text { mombin aqueous leaf extract and } 40 \mathrm{mg} / \mathrm{kg} \\
\text { body weight of PHZ }\end{array}$ \\
E & Low Dose & $\begin{array}{l}150 \mathrm{mg} / \mathrm{kg} \text { body weight of Spondias } \\
\text { mombin aqueous leaf extract and } 40 \mathrm{mg} / \mathrm{kg} \\
\text { body weight of PHZ } \\
40 \mathrm{mg} / \mathrm{kg} \text { body weight of PHZ only }\end{array}$ \\
& Extract and PHZ &
\end{tabular}

\section{Sample collection}

After 21 days of administration and induction, the animals were weighed, anesthetized and cut open (sacrificed). Blood samples were collected directly from the aorta using sterile syringes, by cardiac and aortic puncture from the heart and aorta of each rat into EDTA sample bottles. The blood samples were further subjected to hematological analysis.

The spleen were excised from the sacrificed rats and promptly transferred into $10 \%$ formal saline for fixation and subsequent use for histological analysis.

\section{Histological procedure}

The spleen in $10 \%$ formal saline was dehydrated by passing the tissues through increasing grades of alcohol (70\%, 90\% and 100\%) respectively. The tissues were left in $70 \%$ alcohol for $2 \mathrm{~h}, 90 \%$ alcohol for $18 \mathrm{~h}$ (overnight) and $100 \%$ alcohol for $4 \mathrm{~h}$ (with the solution changed twice). During clearing, the tissues were immersed in xylene for $5 \mathrm{~h}$ to allow the alcohol to be completely removed. Infiltration of the tissues was carried out in an oven using molten paraffin wax at a temperature range of $56^{\circ} \mathrm{C}$ to $60^{\circ} \mathrm{C}$. Three changes each at $15 \mathrm{~min}$ (twice) and $30 \mathrm{~min}$ once were done. During embedding, the molten paraffin wax was poured into the embedding mould and the infiltrated tissues were placed in it. The orientations of the tissues were such that both longitudinal and transverse sections were cut. The molten paraffin wax was allowed to cool and form the tissue block. Prior to sectioning, the tissue blocks were trimmed and mounted on a wooden block holder. During sectioning, the tissues were clipped to the microtome and sectioned at the thickness of five microns. Sections came out as ribbon and were placed in $20 \%$ alcohol for spreading of the tissues. The ribbons were cut and floated in water bath at a temperature of $30{ }^{\circ} \mathrm{C}$. The sectioned tissues were placed in xylene for 5 min to remove paraffin wax from the tissues. Hydration was carried out by passing the tissues through decreasing grades of alcohol $(100 \%, 90 \%$ and $70 \%)$ and water for $5 \mathrm{~min}$ each. The tissues were stained in haematoxylin for $10 \mathrm{~min}$ and washed in water for $2 \mathrm{~min}$. They were differentiated in $1 \%$ acid alcohol briefly and then washed in water. They were subsequently counterstained in eosin for $5 \mathrm{~min}$ and rinsed in 90\% alcohol. Dehydration was done in $90 \%$ alcohol and two changes of absolute alcohol at $5 \mathrm{~min}$ each. The tissues were thereafter cleared in xylene for $5 \mathrm{~min}$ and the slides mounted with cover slip using Canada balsam.

\section{Hematological analysis}

About $2 \mathrm{mls}$ of the blood samples were aspirated into the chamber of the Human Automated Hematology System Analyzer (ERMA PCE 210, ERMA, Japan) and diluted with isotonic saline solution. The parameters analyzed included Haemoglobin Concentration ( $\mathrm{HbC})$, Haematocrit (HCT), Red Blood Cell count (RBC), White Blood Cell count (WBC), Lymphocyte count, Platelets count (PLT), Mean Corpuscular Volume (MCV), Mean Corpuscular Haemoglobin $(\mathrm{MCH})$ and Mean Corpuscular Haemoglobin Concentration (MCHC).

\section{Statistical analysis}

The data were analyzed using descriptive and inferential statistics. Significance difference of means was determined using one-way analysis of variance (ANOVA) at 95\% confidence interval. Statistical significance was set at $P<0.05$.

\section{Results}

Histological sections of the Spleen and haematological parameters of the experimental rats.

Figure 1 shows the histological sections of the spleen of the experimental rats. In the control group, the red and white pulp as well as the sinuses of the spleen appears normal. In group F, given PHZ only, there were contraction of the lymphoid follicles and moderate expansion of the red pulp. The spleen of the rats in group B (given low dose of Spondias mombin aqueous leaf extract only) showed mild sinus histiocytosis and red pulp expansion while the spleen of the rats in group $\mathrm{E}$ (given the low dose extract and PHZ) showed moderate expansion of the red pulp and mild sinus histiocytosis. Also, the spleen of the rats in group C (given high dose of the extract) showed moderate red pulp expansion and histiocytosis while the spleen of the rats given high dose of the extract and PHZ (group D) mild red pulp expansion, mild follicular activation and sinus histiocytosis.

In Fig. 2, there was a significant $(p<0.05)$ increase in the weight of the spleen in group $\mathrm{F}$ and a significant $(\mathrm{p}<0.05)$ decrease in the weight of the spleen in group $\mathrm{C}$ compared with control group. There were no significant $(p>0.05)$ differences between the initial and 

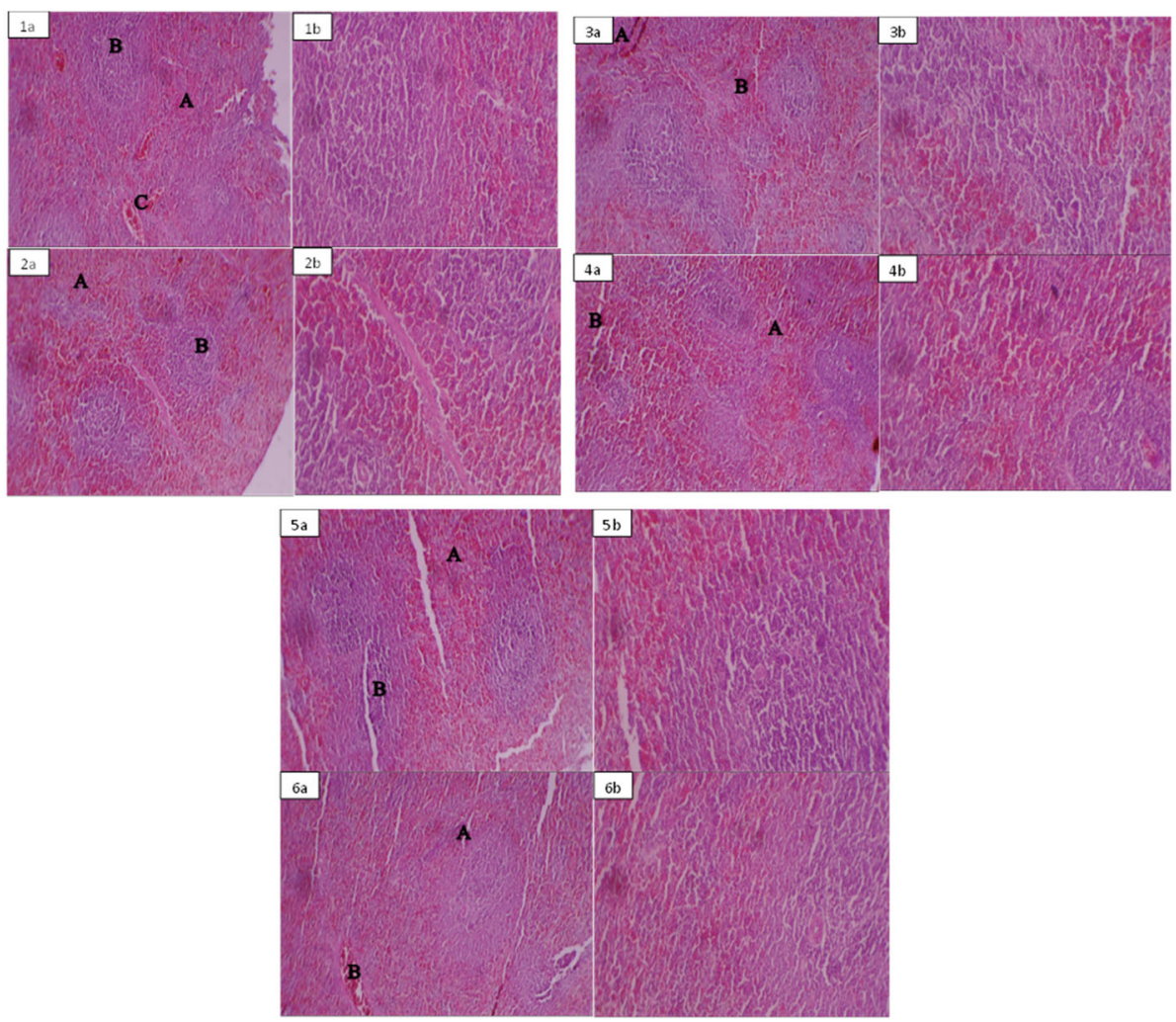

Fig. 1 Histological sections of the Spleen. Plate 1a (Control) - Spleen section showing A (red pulp), B (white pulp) and C (sinuses) [H\&E $\times 40]$ Plate $\mathbf{1 b}$ (Control) - Higher magnification of A and B [H\&E $\times 100]$. Plate 2a (Group F) - Spleen section showing A (moderate expansion of red pulp) and B (contraction of lymphoid follicles) [H\&E $\times 40]$. Plate $\mathbf{2 b}$ (Group F) Higher magnification of A and B [H\&E $\times 100]$. Plate 3a (Group B) Spleen section showing A (mild sinus histiocytosis) and B (red pulp expansion) [H\&E $\times 40]$. Plate $\mathbf{3 b}$ (Group B) Higher magnification of A and B [H\&E $\times 100]$. Plate 4a (Group E) Spleen section showing A (moderate red pulp expansion) and B (mild sinus histiocytosis) [H\&E $\times 40]$. Plate 4b (Group E) Higher magnification of A and B [H\&E $\times 100]$. Plate 5a (Group C) Spleen section showing A (moderate red pulp expansion) and B (histiocytosis) [H\&E $\times 40]$. Plate $\mathbf{5 b}$ (Group C) Higher magnification of A and B [H\&E $\times 100]$. Plate $\mathbf{6 a}$ (Group D) Spleen section showing A (mild red pulp expansion) and B (mild follicular activation and sinus histiocytosis) [H\&E $\times 40]$. Plate $6 \mathbf{b}$ (Group D) Higher magnification A and B $[H \& E \times 100]$

final body weight across all the treated groups and control.

Figure 3 show significant $(\mathrm{p}<0.05)$ decreases in the $\mathrm{RBC}$ count in all the treated groups as compared with the control group. However, the decrease in group $\mathrm{F}$ is more pronounced. There were no significant $(p>0.05)$ changes in haemoglobin concentrations across all the treated groups as compared with the control group. There were no significant $(\mathrm{p}>0.05)$ changes in the haematocrit across all the treated groups as compared with the control group, although group F shows a slight reduction as compared with other groups. There were significant $(p<0.05)$ increases in the MCV across all the treated groups as compared with the control group, with the increase more pronounced in groups $\mathrm{D}$ and $\mathrm{E}$.

In Fig. 4 , there were significant $(\mathrm{p}<0.05)$ increases in the $\mathrm{MCH}$ across all the groups as compared with the control group, with the increase more pronounced in group E. There was a significant $(P<0.05)$ decrease in the $\mathrm{MCHC}$ in group D compared with control group, while in other groups, there were no significant $(P>$ $0.05)$ changes as compared with control group. There were no significant $(\mathrm{P}>0.05)$ changes in the platelet counts across all the groups as compared with the control group. Although group E show a decrease as compared with the other groups. There were no significant $(P>0.05)$ changes in the plateletcrit across all the groups as compared with the control group. Although groups D and E shows a decrease as compared with the other groups.

In Fig. 5 , there were no significant $(P>0.05)$ changes in the total white blood cell count across all the groups as compared with the control group. Although group F show a decrease as compared with the other groups. There were no significant $(\mathrm{P}>0.05)$ changes in the lymphocyte count across all the groups as compared with the control group. Although group F show a decrease as compared with the other groups. 

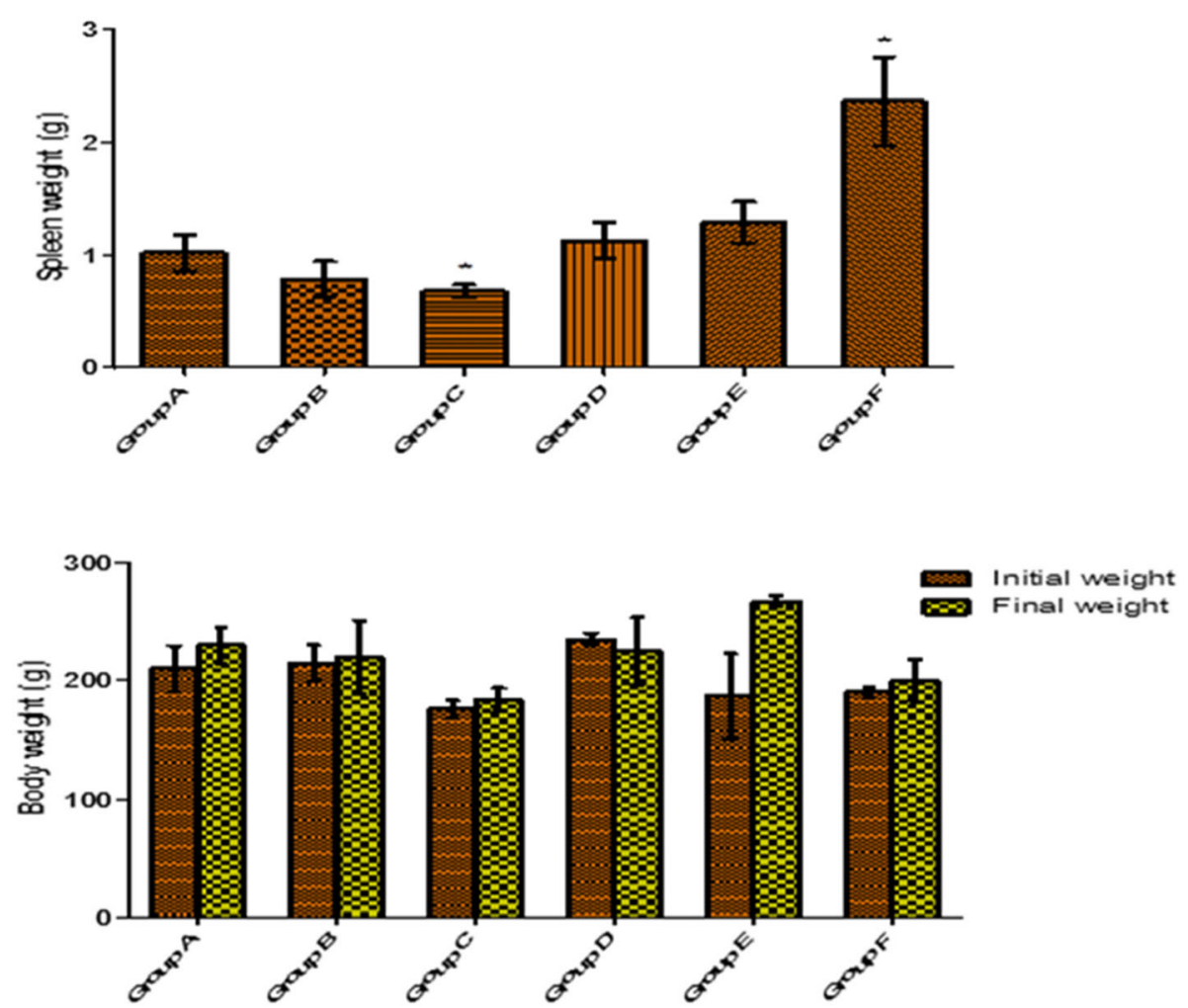

Fig. 2 Shows the weight of the spleen and total body weight of the experimental rats following the administration of Spondias mombin extract and $\mathrm{PHZ}$ at different doses

\section{Discussion}

The spleen plays important roles in the functioning of the immune system, removal of old red blood cells and as reservoir of blood which can be valuable in case of hemorrhagic shock, as well as the recycling of iron. As a part of the mononuclear phagocyte system, the spleen mobilizes hemoglobin removed from senescent red blood cells [30]. Asplenia, a non-functioning spleen and hyposplenia, a partially functioning spleen, can result from congenital defect, damage by trauma, diseases such as sickle cell anemia, or use of some drugs like PHZ. These conditions may cause a modest increase in circulating white blood cells and platelets, a diminished response to some vaccines, and an increased susceptibility to infection [4]. Anemia is characterized by reduction in red cell mass or reduction in the quantity and quality of hemoglobin [31]. It results in decreased oxygen concentration in the tissues and ultimately affects cellular metabolism [32]. Its causes can generally be classified into four main classes which are reduced production of hemoglobin, increased destruction of hemoglobin or blood loss and splenic pooling [31]. In this study, histological sections of the tissues of the spleen of the experimental rats show normal red pulp, white pulp and sinuses in the control group. But group F (given PHZ only) comparatively show moderate expansion of the red pulp and contraction of lymphoid follicles. This is an indication of the toxic effect of PHZ to the spleen which may likely affect its functions as stated above. Agbor et al. [9] and Xie et al. [8] previously used PHZ-induced anemic rats as a model for the study of the hematinic effects of PHZ and reticulocyte researches or erythrocyte senescence. The administration of the extract at low and high doses caused mild increase in the number of certain immune cells in the sinus and moderate red pulp expansion. This was also observed in the groups given low and high doses of the extract with PHZ. However, the increase in immune cells as well as the expansion of the red pulp was more pronounced, probably due to the effect of increased dose of the extract. Also, in the group given high dose of the extract with PHZ, there was mild follicular activation and sinus histiocytosis. This may suggest that the plant extract is probably effective at protecting the spleen against the harmful effect of PHZ, possibly by activating the lymphoid follicle. The extract induced activation of the lymphoid follicle to varying degrees of mild to moderate levels, while also increasing the population of red cells in the red pulp. It was also observed that the weight of the spleen was significantly higher in the group given PHZ only and significantly lower in the group given high dose of the extract and PHZ, while the weight was not significantly affected in 

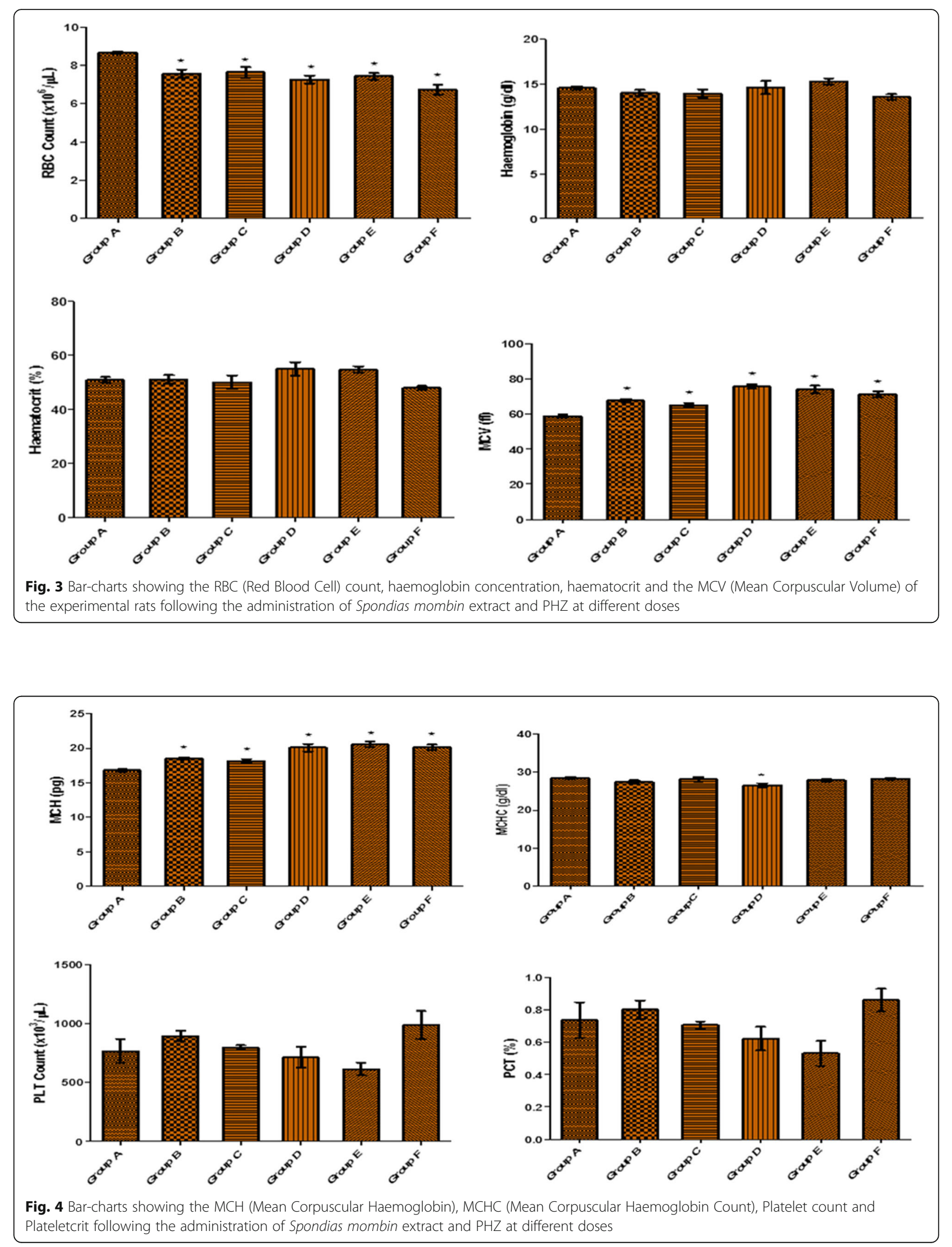

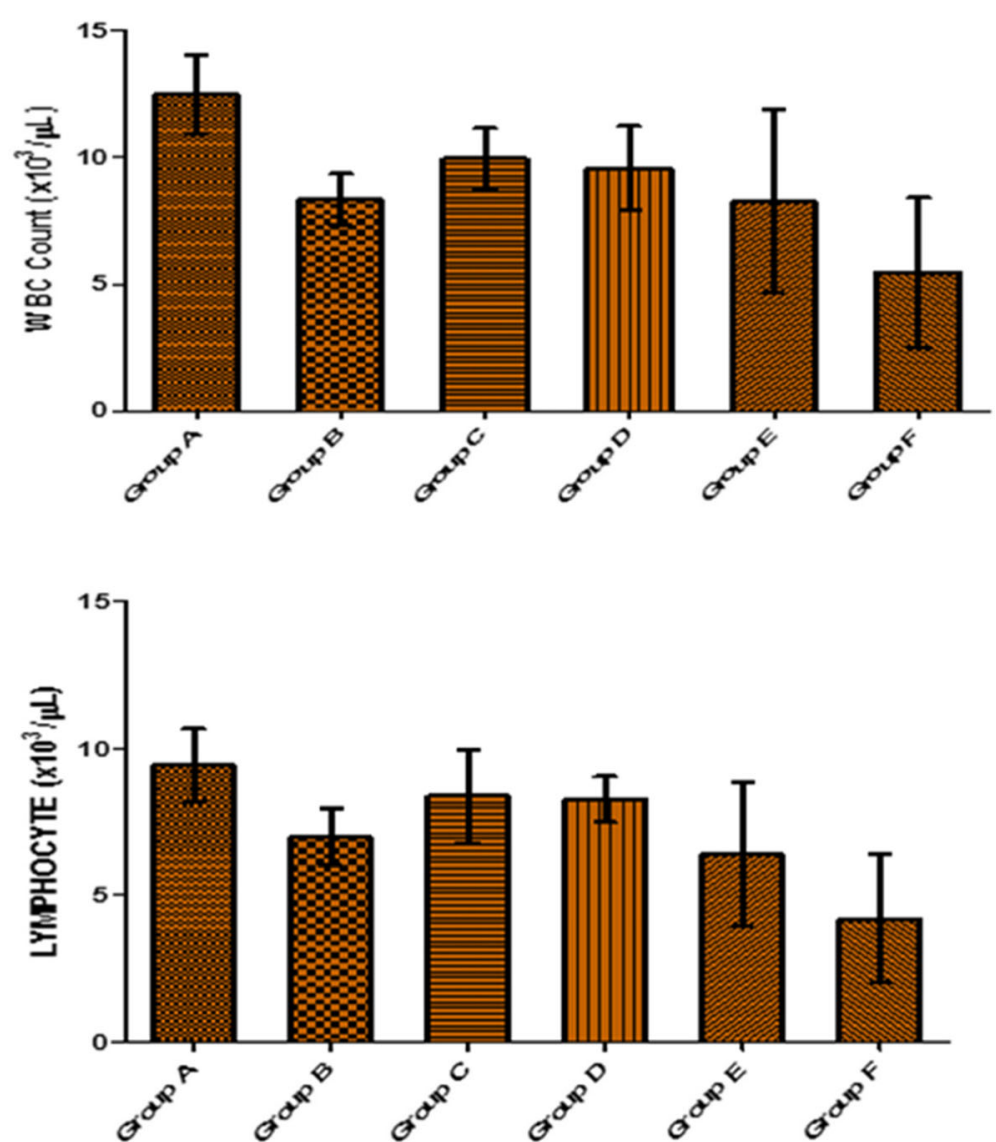

Fig. 5 Bar-charts showing the total WBC (White Blood Cell) count and Lymphocyte count following the administration of Spondias mombin extract and $\mathrm{PHZ}$ at different doses

other groups. This is in agreement with previous findings which indicate increases in the weight of the spleen of experimental animals administered with PHZ [33]. The increase in weight of the spleen is due to the increased erythropoiesis which attempts to replace the destroyed red blood cells by PHZ [34]. The lower weight observed in the other groups points at the possible protective effect of the plant extract on the spleen against the toxic effect of PHZ. Thus, the extract can be said to ameliorate the anemic effects of PHZ. However, the general body weights of the experimental rats were not significantly affected, as observed.

Hematological analysis of the blood samples from the experimental rats indicates that there were significant decreases in the $\mathrm{RBC}$ count in all the treated groups as compared with the control group. But the decrease in the group given only PHZ was more pronounced. There were no significant changes in hemoglobin concentrations across all the treated groups as compared with the control group. And there were no significant changes in the hematocrit across all the treated groups as compared with the control group. But the group given PHZ only shows a comparatively lower hematocrit as compared with other groups. The decrease in Red blood cells, hemoglobin concentration and hematocrit in group F (given PHZ only) as compared with extract-treated groups equally points to the anemic effect of PHZ [33, 34] as well as the ameliorative effect of Spondias mombin, which resulted in the increases in these parameters, comparatively, in the extract treated groups. The comparative increase in the hematological parameters in the groups given only the extract gives a possible scientific rationale for its use as hematinic agent. Other researchers have shown that some medicinal plants could be used as hematinic agents as they tend to protect against anemic conditions [26-28].

Our study also showed that there were significant increases in the MCV across all the treated groups as compared with the control group, with the increase more pronounced in the groups given high and low dose of the extract with PHZ. There were significant increases in the $\mathrm{MCH}$ across all the groups as compared with the control group, with the increase more pronounced in group $\mathrm{E}$ (given low dose and PHZ). Significant decrease in the $\mathrm{MCHC}$ in the group given high dose and PHZ (group D) compared with control group, while in other groups, there were no significant 
changes as compared with control group. Also there were no significant changes in the platelet counts across all the groups as compared with the control group, although group E (given low dose and PHZ show a decrease as compared with the other groups. Results also show that there were no significant changes in the plateletcrit across all the groups as compared with the control group, although groups D and $\mathrm{E}$ show a decrease as compared with the other groups. There were no significant changes in the total white blood cell count across all the groups as compared with the control group, but group F (given PHZ only) showed a decrease as compared with the other groups. It was also observed that there were no significant changes in the lymphocyte count across all the groups as compared with the control group, but the group given PHZ only showed a decrease in the lymphocyte count as compared with the other groups. It was obvious that the production of white blood cells was suppressed by PHZ. However, the administration of the extract at different doses tends to activate the lymphoid follicle, as shown in the histological results, thereby increasing above-mentioned parameters in the blood.

\section{Conclusion}

The findings of our study suggest the hematinic effect of Spondias mombin aqueous leaf extract and its possible use in ethno-medicine in managing anemic conditions. It also shows its potential in protecting against the spleenotoxic effect of PHZ.

\section{Abbreviations}

ANOVA: Analysis of Variance; PHZ: Phenylhydrazine; RBC: Red Blood Cells; MCV: Mean Corpuscular Volume; MCH: Mean Corpuscular Haemoglobin; MCHC: Mean Corpuscular Haemoglobin Count; WBC: White Blood Cells

\section{Acknowledgements}

The Authors acknowledge the Department of Anatomy, School of Basic Medical Sciences, College of Medical Sciences, University of Benin, (Edo State, Nigeria) for providing the necessary laboratory facilities.

\section{Authors' contributions}

$\mathrm{SOI}$ conceived, designed and performed the experiments; SOO and KO performed the analysis and interpretation of the data, as well as preparation of the draft of the manuscript. All authors have reviewed and approved the final draft of the manuscript.

\section{Authors' information}

$\mathrm{SOI}, \mathrm{PhD}$, is a senior lecturer in the department of anatomy, college of medical sciences, university of Benin, Nigeria. SOO, is a lecturer II in the department of biochemistry, university of Benin, Nigeria. $\mathrm{KO}, \mathrm{PhD}$, is a senior lecturer and research scientist in the department of biochemistry, lgbinedion University, Okada, Nigeria.

\section{Funding}

This research did not receive any specific grant from funding agencies in the public, commercial, or not-for-profit sectors.

\section{Availability of data and materials}

Data and materials on which conclusions of the manuscript rely are presented in the main paper.

\section{Ethics approval and consent to participate}

The experimental procedures performed on the animals were as approved by the Research Ethics Committee of the College of Medical Sciences, University of Benin, Nigeria. The use of rats for the study was also according to the Ethical Guidelines Involving Whole Animal Testing of the Research Ethics Committee of the College of Medical Sciences, University of Benin, Nigeria.

\section{Consent for publication}

Not Applicable.

\section{Competing interests}

The authors wish to state that there are no competing interests associated with this publication and there has been no significant financial support for this work that could have influenced its outcome.

\section{Author details}

'Department of Anatomy, School of Basic Medical Sciences, College of Medical Sciences, University of Benin, Benin City, Edo State, Nigeria. ${ }^{2}$ Department of Biochemistry, Faculty of Life Sciences, University of Benin, Benin City, Edo State, Nigeria. ${ }^{3}$ Department of Biochemistry, College of Basic Medical Sciences, Igbinedion University, Okada, Benin City, Edo State, Nigeria.

Received: 30 December 2019 Accepted: 20 May 2020

Published online: 24 May 2020

\section{References}

1. Kim CC, Christopher SN, Emily BW, Baidong H, Anthony LD, Joseph LD. Splenic red pulp macrophages produce type I Interferons as early sentinels of malaria infection but are dispensable for control. PLoS One. 2012;7(10): e48126.

2. Ronaldo AL, Denny FMV, Leonardo SV, Andy P. Is there a relationship between lipids metabolism and splenic surgeries? Acta Cir Bras. 2012;27(11): 751-6.

3. Brender MD, Erin A, Burke MA, Richard M, Glass MD. Spleen Patient. J Am Med Assoc. 2005;294(20):2660.

4. Jia T, Pamer EG. Immunology: Dispensable but not irrelevant. Science. 2009; 325(5940):549-50

5. Dornfest BS, Lapin DM, Adu S, Naughton BA. Dexamethasone suppresses the generation of Phenylhydrazine induced anaemia in the rat. Exp Biol Med. 1992;199:491-500.

6. Terszowski G, Waskow C, Conradt P, Lenze D, Koenigsmann J, Carstanjen D, et al. Prospective isolation and global gene expression analysis of the erythrocyte colony-forming unit (CFU-E). Blood. 2005;105:1937-45.

7. Golab J, Dominika O, Pawel M. Erythropoietin restores the antitumor effectiveness of photodynamic therapy in mice with chemotherapyinduced Anemia. Clin Cancer Res. 2002;8:1265-70.

8. Xie L, Li G, Zong-yi Y, Wei-juan Y, Da-song S, Zong-yao W. The microrheological changes in the course of erythrocyte senescence after phenylhydrazine injection. Clin Hemorheol Microcirc. 2003;28(1):5-11.

9. Agbor GA, Oben JE, Ngogang JY, Xinxing C, Vinson JA. Antioxidant capacity of some herbs/spices from Cameroon: a comparative study of two methods. J Agric Food Chem. 2005:53:6819-24.

10. Edgar R, Michael D, Alex EL. Gene expression omnibus: NCBI gene expression and hybridization array data repository. Nucleic Acids Res. 2002; 30(1):207-10.

11. Balick MJ, Elisabetsky E, Laird SA. Medicinal resources of the tropical Forest: biodiversity and its importance to human health. New York: Columbia University Press; 1996.

12. Omage K, Azeke AM. Medicinal potential of Acalypha wilkesiana leaves. Adv Res. 2014;2(11):655-65.

13. Gilani AH, Shah AJ, Ghayur MN, Majeed K. Pharmacological basis for the use of turmeric in gastrointestinal and respiratory disorders. Life Sci. 2005;76: 3089-105.

14. Romeiras MM, Maria CD, Bucar I, Luís C. Medicinal plants used to treat neurological disorders in West Africa: a case study with Guinea-Bissau Flora. Am J Plant Sci. 2012;3:1028-36.

15. Rasool HBA. Medicinal plants (importance and uses). Pharmaceut Anal Acta. 2012;3:e139. https://doi.org/10.4172/2153-2435.1000e139. 
16. Omage OS, Orhue NEJ, Omage K. Evaluation of the phytochemical content, in vitro antioxidant capacity, biochemical and histological effects of Dennettia tripetala fruits in healthy rats. Food Sci Nutr. 2019;7:6-75.

17. Omage K, Azeke AM, Omage OS. Evaluation of the efficacy of Acalypha wilkesiana leaves in managing cardiovascular disease risk factors in rabbits exposed to salt-loaded diets. Clin Phytosci. 2018:4(1):1-7.

18. Corthout J, Pieters LA, Claeys MV, Berghe DA, Viletinck AJ. Antiviral, Ellagitannins from Spondias mombin. Phytochemistry. 1992;30:1190.

19. Ayoka AO, Akomolafe RO, Iwalewa EO, Akanmub MA, Ukponmwan OE. Sedative, antiepileptic and antipsychotic effects of Spondias mombin (Anacardiaceae) in mice and rats. J Ethnopharmacol. 2006;103:166-75.

20. Nworu CS, Akah PA, Okoye FBC, Proksch P, Esimone CO. The effects of Phyllanthus niruri aqueous extract on the activation of murine lymphocytes and bone marrow-derived macrophages. Immunol Investig. 2010;39(3):245-67.

21. Ajiboye B, Ibukun E, Edobor G, Ojo A, Onikanni S. Chemical composition of Senecio biafrae leaf. Scientific J Biol Sci. 2013;2:152-9.

22. De Ferreyra EC. Planta que curan las heridas del hombrey los animals. Boletin de lima 1-12. In: Villegas et al: Evaluation of the wound healing activity of selected traditional medicinal plants from Peru. J Ethnopharmacol. 1981;55:193-200.

23. Rodrigues KF, Hasse M. Antimicrobial activities of secondary metabolites produced by endophytic fungi from Spondias mombin. J Basic Microbiol. 2000;40:261-7

24. Abdulkabir OO, Ibrahim AO, Ajmal K. Determination of in-vitro biochemical activities of Reflevone, a new natural organic compound. Nat Prod Res. 2017;7(6):427-37.

25. Adusi-Poku Y, Sittie A, Mensah MLK, Sarpong K, Fleischer TC. Effectiveness and safety assessment of mist tonica as herbal haematinic. Afr J Tradit Complement Altern Med. 2008;5:115-9.

26. Adias TC, Ajugwo AO, Erhabor T, Nyenke CU. Effect of pumpkin extract (Telfairia occidentalis) on routine haematological parameters in acetoneinduced oxidative stress albino rats. Am J Food Sci Technol. 2013;1:67-9.

27. Okochi YI, Akpotuzor J, Alli LA. Comparism of an African herbal formula with commercially available haematinics. African J Biotechnol. 2013;2:219-27.

28. Akah PA, Nnamani CE, Nnamani PO. Prevalence and treatment outcome of vulvovaginal candidiasis in pregnancy in a rural community in Enugu state, Nigeria. J Med Med Sci. 2010:1(10):447-52

29. Mebius RE, Kraal G. Structure and function of the spleen. Nat Rev Immunol. 2005:5:606-16.

30. Kelly A, Munan L. Hematolytic profile of natural populations: red cell parameters. Br J Haematol. 1997;35:153-60.

31. Kasper DL, Braunwald E, Fauci AS, Hauser SL, Longo DL, Jameson JL. Harrison's Principle of Internal Medicine, vol. vol. 1. 16th ed. Lincoln: McGraw-Hill Professional; 2004.

32. Singh $\mathrm{H}$, Husain $\mathrm{T}$, Agnihotri P, Pande PC, Khatoon S. An ethnobotanical study of medicinal plants used in sacred groves of Kumaon Himalaya, Uttarakhand, India. J Ethnopharmacol. 2014;154(1):98-108.

33. Ajugwo AO, Mounbegna PE, Kemajou TS, Ofokansi VC. Effects of Moringa oleifera leaves extract on Haematological parameters of Phenylhydrazine Anaemia induced Wistar rats. Int J Pub Health Safe. 2017;2:139.

34. Flanagan J, Lessler MA. Controlled phenylhydrazine-induced reticulocytosis in rat. The Ohio J Sci. 2000;70:300-4.

\section{Publisher's Note}

Springer Nature remains neutral with regard to jurisdictional claims in published maps and institutional affiliations.

\section{Submit your manuscript to a SpringerOpen ${ }^{\circ}$ journal and benefit from:}

- Convenient online submission

- Rigorous peer review

- Open access: articles freely available online

- High visibility within the field

- Retaining the copyright to your article

Submit your next manuscript at $\boldsymbol{\nabla}$ springeropen.com 